\title{
The Seedling Structure of Araucaria Bidwillii.
}

\author{
BY \\ F. J. F. SHAW, B.Sc. (LoND.), A.R.C.S. \\ With Plate XXI and six Diagrams in the Text.
}

THE seedling structure of Gymnosperms has till lately been somewhat neglected. In a recent paper, Hill (2) has described the transition phenomena in some species, chiefly Cupressineae and Taxaceae, and at an earlier date Seward (4) has given a partial account of the seedling anatomy of two species of Araucariae, the two species dealt with being $A$. imbricata and A. Bidwillii. The present paper is concerned only with Araucaria Bidreillii, which was not treated in detail by Seward and Ford. In view of the uniformity found to exist in seedling Gymnosperms, so far as at present investigated, the wide range of variation in the number of cotyledonary bundles and in the structure of the root lends considerable interest to this species.

The specimens were about $16 \mathrm{~cm}$. long and $1.5 \mathrm{~cm}$. broad at the widest part of the hypocotyl. In normal cases a seedling consists of a swollen or tuberous hypocotyl passing gradually into a thin root (Pl. XXI, Fig. I) ; none of the specimens showed cotyledons. The whole of the swollen portion, from the point at which the cotyledonary tube joins the axis, to a level at which the main axis runs on without any essential change in diameter, is considered to be the hypocotyl. In Diagram IV, Fig. I3, Sections 3 to 8 , corresponding to the Figures of same number in Diagrams I and II, are in the hypocotyl. The plumular shoot at the apex of the seedling is enclosed in a cotyledonary tube formed from the persistent fused bases of the cotyledons, the whole external surface is covered with cork.

\section{Transition Phenomena.}

For the elucidation of the course of the vascular bundles, series of transverse sections were cut by hand from the apex to the base of numerous seedlings. Longitudinal sections were taken from certain portions to check the results.

At the apex of the seedling the plumular bundles $(p l . b$. $)$ form a ring which runs downwards as far as the point at which the cotyledonary tube joins 
the hypocotyl. At this level they spread outwards, allowing for the insertion of the numerous bundles (c.b.) from the cotyledons (Diagram I, Figs. I, 2). The number of bundles $(c . b$. ) entering the hypocotyl from the cotyledonary tube is subject to great variation. In the tube itself there are usually from I2-I 6 small collateral bundles. These bundles consist chiefly of secondary xylem $(x$.$) , the primary xylem \left(p \cdot x^{\prime}.\right)$ being practically restricted to the endarch protoxylem. As the bundles enter the hypocotyl, they become associated, sometimes in pairs, sometimes in threes, and these groups pass
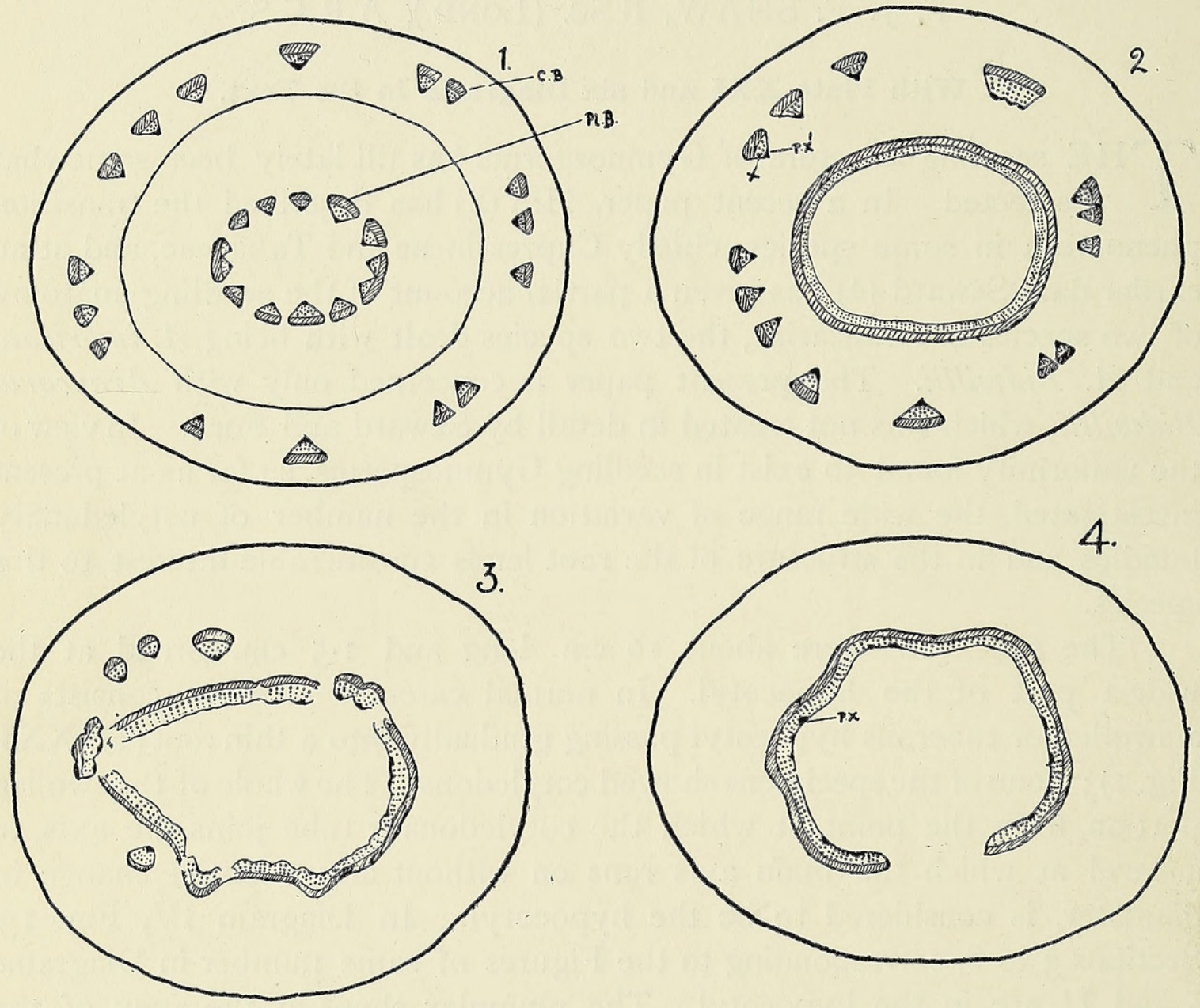

DIAGRAM I.

inwards and fuse with the vascular tissue from the plumule (Diagram I, Fig. 3). The bundles derived from the cotyledons fuse with those from the shoot to form a continuous ring in which it is impossible to discern the limits of the vascular tissue from either source (Diagram I, Fig. 4). Lower down, this ring breaks up into from $5^{-7}$ curved segments $(s$.$) , with the concavity out-$ wards, and each segment then divides into two bundles which divaricate and approach those derived from adjacent segments (Diagram II, Figs. 5, 6). In this way there arises in the upper portion of the hypocotyl a ring of from 5-7 pairs of vascular bundles, the two individuals of any one pair being inclined towards each other, and originally derived from different segments. 
The above account only represents the course of the vascular bundles in a general sense; as a matter of fact, hardly any two seedlings seem to agree precisely in the manner in which the bundles in the hypocotyl are differentiated out of those from the cotyledons and plumule. Numerous specimens were investigated in the hope of establishing the relationships between the bundles appearing in the hypocotyl and those entering from the cotyledonary tube. As a general rule, owing to the complete fusion of cotyledonary and plumular strands, and the large amount of secondary thickening, it is
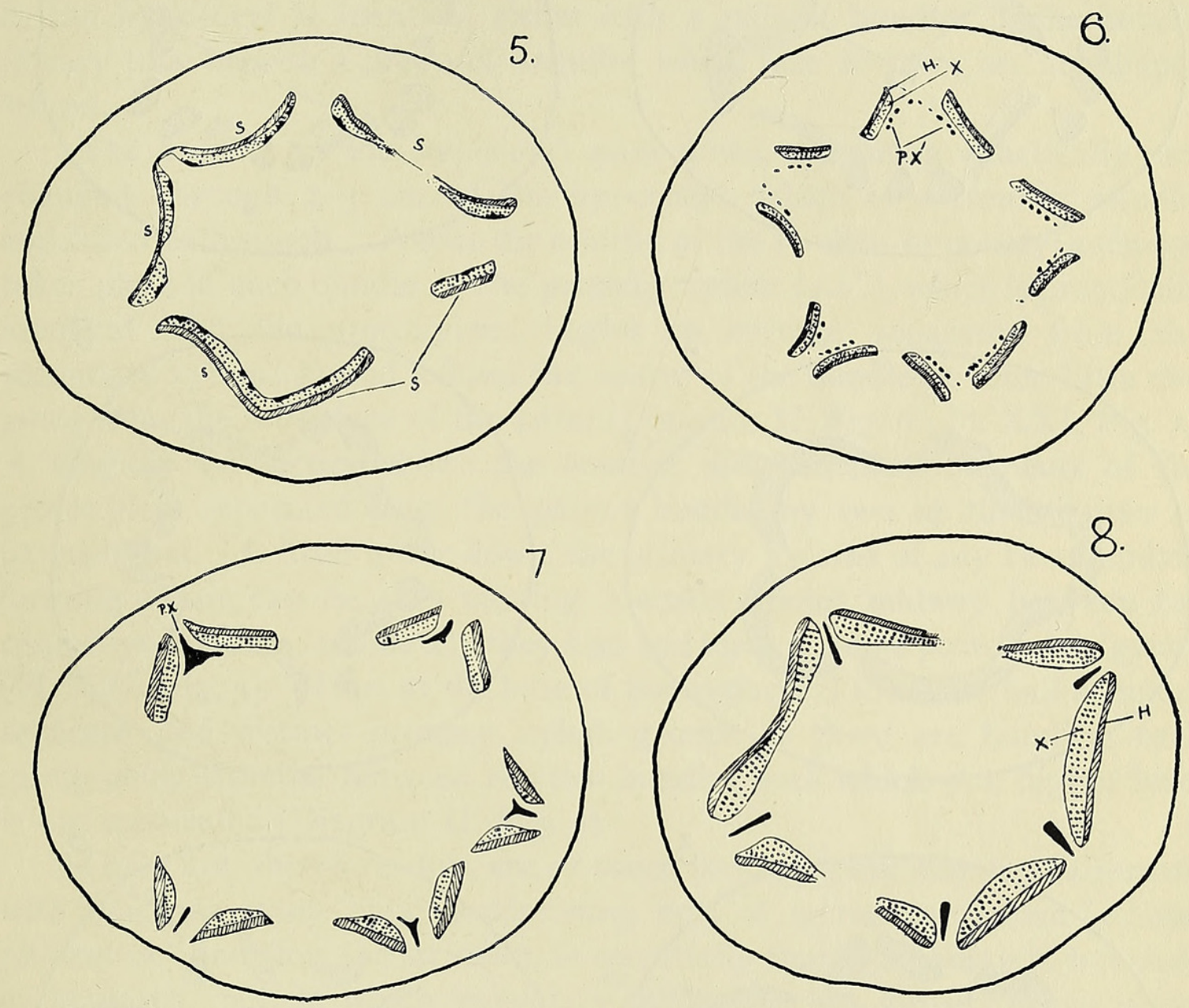

DiAgraM II.

impossible to trace any one bundle in the hypocotyl back to a particular bundle in the cotyledonary tube. In two specimens, however, the cotyledonary bundles seemed to preserve a certain amount of individuality throughout their fusion with the vascular tissue from the plumule; here, accordingly, it was possible to trace them into connexion with those in the hypocotyl.

In one of these seedlings (Diagram III, Fig. I) fourteen bundles (c.b.) entered the hypocotyl from the cotyledonary tube; they were arranged in a ring of four groups of three bundles and one group of two bundles. These five groups of bundles fuse with the plumular strands, each group as it does 
so forming an arc-shaped strand with the concavity inwards (Diagram III, Fig. 2) ; each of these strands subsequently splits into two bundles with their xylems obliquely facing each other (Diagram III, Fig. 3). Thus a ring of
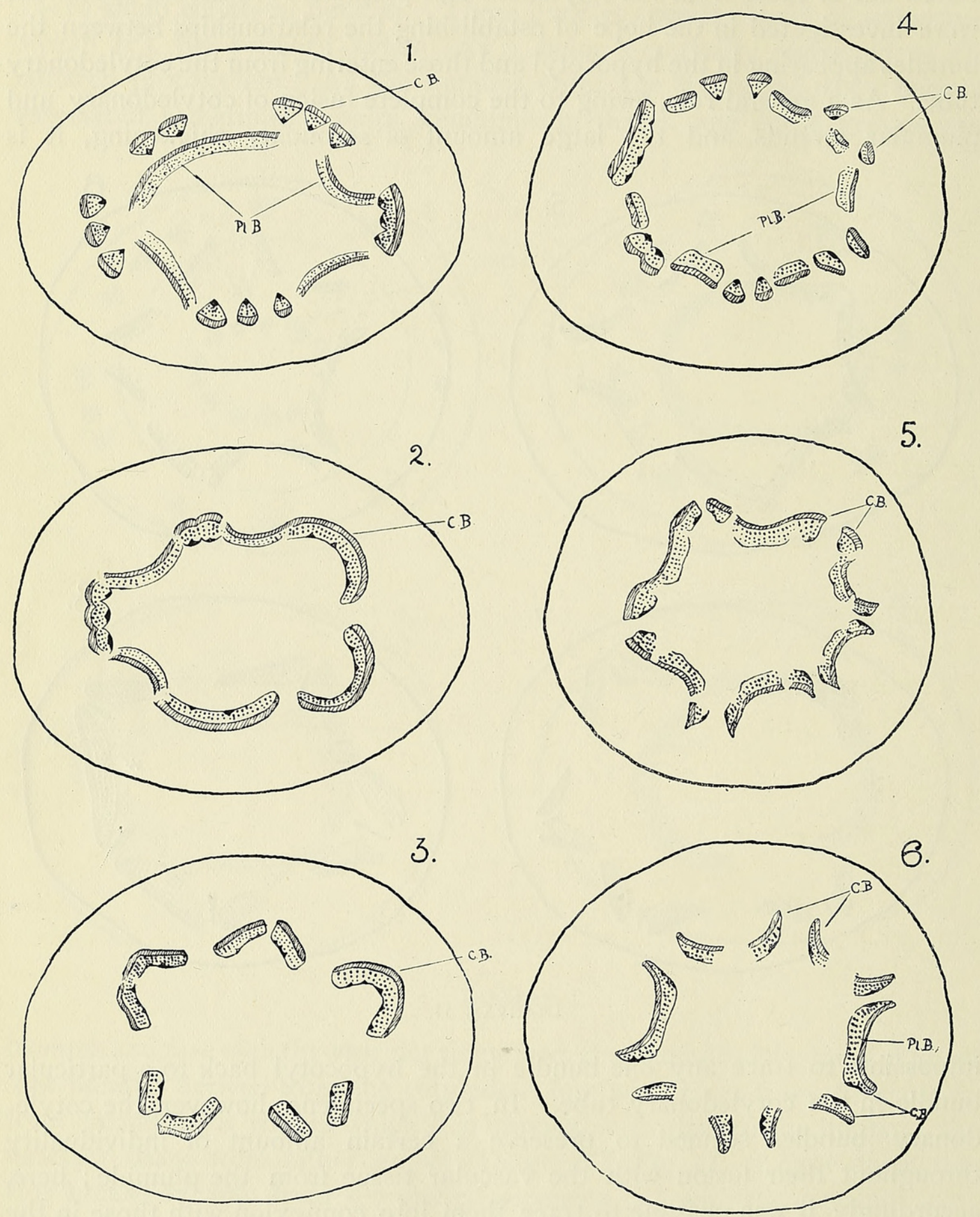

DIAGRAM III.

five pairs of bundles is formed, as in the previous case, with this difference : that each pair of bundles is derived from the same segment and the segments themselves can be definitely traced back to groups of cotyledonary bundles. 
In the other seedling, the bundles (c.b.) from the cotyledons entered the plumular ring in pairs in such a way that the individual bundles of a pair form the 'horns' of different segments, which, as in the first case, are curved with the concavity outwards (Diagram III, Figs. 4, 5). When, therefore, the segments divide to form the paired bundles in the hypocotyl, each pair is identical with a pair of cotyledonary bundles (Diagram III, Fig. 6).

Thus in both these cases there is evidence that each pair of bundles ir the hypocotyl is identical either with a pair of bundles in the cotyledonary tube or with a group of bundles which fuse to form an arc-shaped strand.

The bundles in the hypocotyl pass down, remaining practically unchanged, through $2-3 \mathrm{~cm}$. of the hypocotyl, which is extremely swollen and filled with starch. About the middle of the swollen hypocotyl a change takes place in each bundle. The primary xylem $\left(p . x^{\prime}.\right)$, which is practically identical with the protoxylem, begins to become separated from the secondary xylem $\left(x_{0}\right)$, and follows the course of the bundle at some little distance from the inner face of the latter (Diagram II, Fig. 6 ; P1. XXI, Fig. 2). A longitudinal section shows the annular and reticulate elements of the protoxylem separated from the parent bundle by two or three layers of parenchyma. A little lower down, the primary xylems of any two bundles, forming a pair, can be seen curving towards a point midway between the respective bundles ; ultimately they fuse and form a single protoxylem group (P1. XXI, Fig. 3). Thus at the base of the hypocotyl there are half as many separate and distinct primary xylem groups as there are bundles, each group being situated between the two bundles with which at a higher level it was associated (Diagram II, Fig. 7).

There are, therefore, five, six, or seven protoxylems, and these alternate with twice as many bundles consisting only of secondary xylem $\left(x_{0}\right)$ and phloem $(h$.$) , and thus the structure is essentially that of a pentarch, hexarch,$ or heptarch root, in which secondary thickening has already taken place. As the hypocotyl decreases in diameter, the separate bundles of secondary xylem and phloem fuse to form continuous tangential bands between the primary xylem groups (Diagram II, Fig. 8) ; it should be noticed that this union is between bundles originally belonging to separate pairs at a higher level. The numbers of seedlings showing heptarch, hexarch, or pentarch structure respectively, were about equal.

The further changes in the vascular system of the root will be described in a specimen which showed pentarch structure in the base of the hypocotyl, though the following remarks, mutatis mutandis, would apply equally to those with hexarch or heptarch structure.

As a rule, the pentarch structure persists for some distance, running through the rapidly narrowing hypocotyl and into the main root; its extent 
can be judged from Diagram IV, Fig. I3, where it runs from Section 7 to about Section 9. At length one side of the pentarch stele appears shorter than the others, owing to two adjacent protoxylem groups curving towards one another in a tangential plane (Diagram IV, Fig. 9). Then these xylems ultimately fuse, giving rise to a tetrarch root. In the process of fusion one protoxylem is commonly dominant, retaining its original size and not undergoing any marked change in position, whilst the other becomes considerably smaller and curves over to fuse with the more central portion of the larger
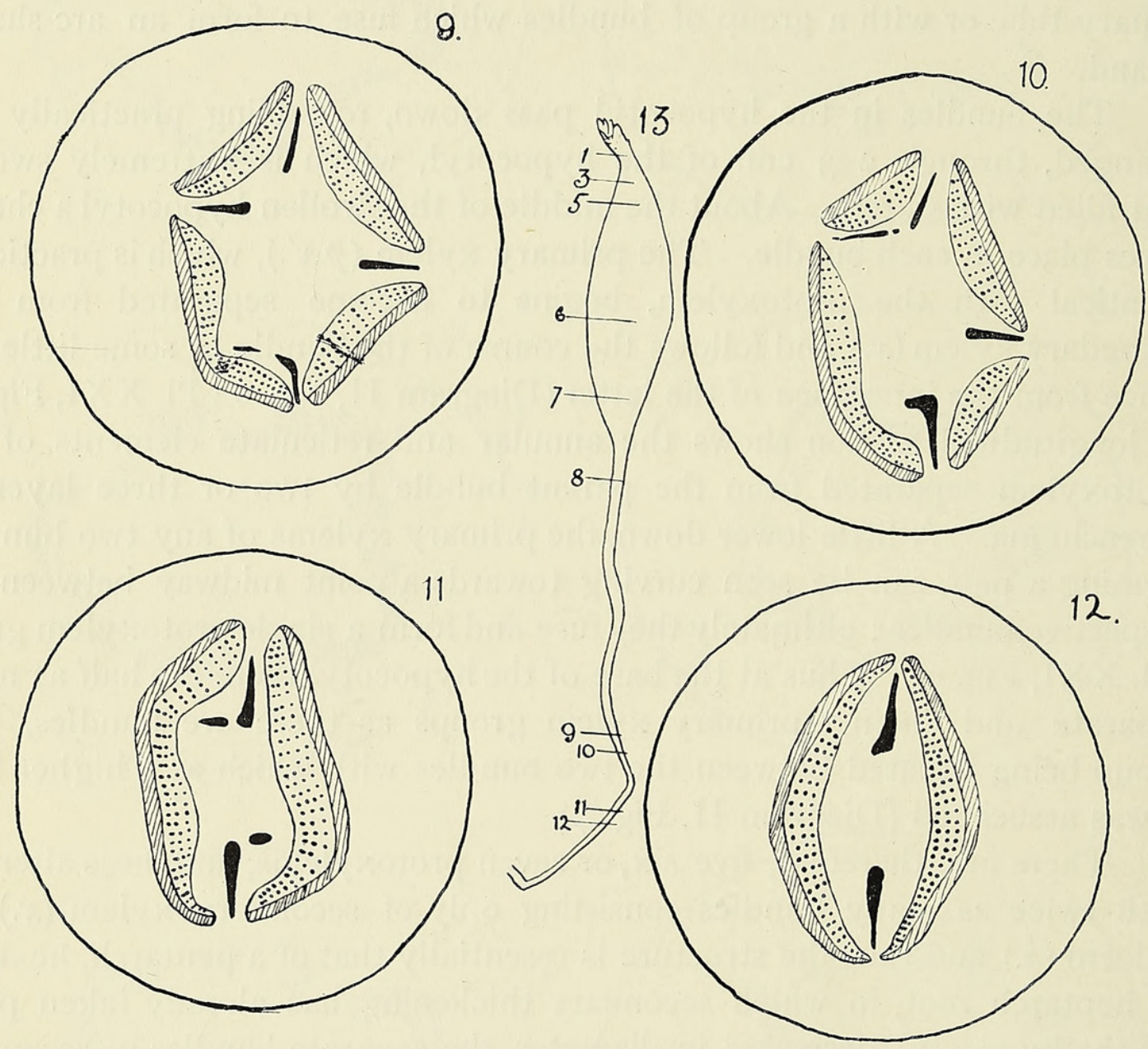

DIAGRAM IV.

group (Pl. XXI, Fig. 4). A similar process now takes place on the opposite side of the root, reducing the structure to triarch, and this passes finally to diarch (Diagram IV, Figs. IO, I I, I 2); the last two changes take place almost simultaneously. In this way the young tap-root is invariably diarch, and consists of a single primary xylem plate flanked by two masses of secondary xylem and phloem, the sole remnants of the former numerous bundles (Diagram IV, Fig. I 2). Throughout the transition, the primary xylem is the only vascular tissue which has undergone any marked change in position, the primary xylem of each bundle in the hypocotyl having moved sideways 
to fuse with that of an adjacent bundle. The secondary xylem and the phloem of the root is linearly continuous with the secondary xylem and phloem of the bundles in the hypocotyl.

The reduction of the root to the diarch type ultimately takes place whether the original structure was pentarch, hexarch, or heptarch. In some specimens, however, the youngest portions of the root still showed triarch structure, the diarch stage not having yet been reached. Had the plants been older the diarch appearance would doubtless have been shown.

Secondary roots are always diarch, and derive their primary vascular tissue from a single primary xylem group lying between two masses of secondary xylem. This was particularly clear in one specimen examined, in which the main tap-root had decayed away; the base of the hypocotyl, therefore, terminated in a blunt projection, on one side of which a thin adventitious root arose. This root was diarch; a transverse section of the hypocotyl, however, showed pentarch structure. On tracing the adventitious root into the hypocotyl, it was found that it arose from a single primary xylem group lying between two bundles; had each primary xylem group given rise to an adventitious root, there would have been five roots in a ring at the base of the withered tap-root.

\section{An Anomalous Seedling.}

One specimen in the material first attracted attention from its abnormal external appearance, a variation which was found to be accompanied by even stranger diversities in the vascular tissue. The seedling in question (Diagram IV, Fig. 9) had a longer, more tuberous hypocotyl than usual ; at the base of the swollen portion of the hypocotyl the seedling took a sharp bend, running at right angles to its former course for some $3 \mathrm{~cm}$.; it then became sharply constricted and continued as a very thin root.

The vascular structure of the seedling was normal down to a point $(p$. about half way along the horizontal portion of the root, here hexarch in structure, derived from six pairs of bundles in the hypocotyl. A section taken at the constriction $(d$.) in the root, about $\mathrm{I} \cdot 5 \mathrm{~cm}$. lower down, showed diarch structure; the transition from hexarch to diarch in the intervening portion $(t$.) was marked by some curious abnormalities.

The hexarch stele passes quickly into pentarch in the normal way; during this process a series of cell-divisions takes place in the pith. The divisions occur tangentially in a zone forming a closed circle ; they give rise to a circular cambium $(c$.$) in the pith, and this cambium produces xylem$ externally and phloem internally. Thus a ring of vascular tissue with inverted orientation is formed inside the root (Diagram V, Fig. I). While this is proceeding, changes take place in the five primary xylem groups; each splits up into several smaller groups which return to the positions which they formerly occupied in the hypocotyl. That is to say, they 
curve away from one another and attach themselves to the inner side of the secondary xylem (Diagram V, Figs. I and 2). At this stage, therefore, the root contains an outer ring of vascular tissue with normal endarch protoxylem and an inner ring with inverted orientation.

A gap now appears in the outer ring, and its cambium becomes continuous with that of the inner round the edges of the gap, the inverted xylem also becoming continuous with the normal (Diagram V, Fig. 2). In this way a stele is formed consisting of a $U$-shaped mass of xylem
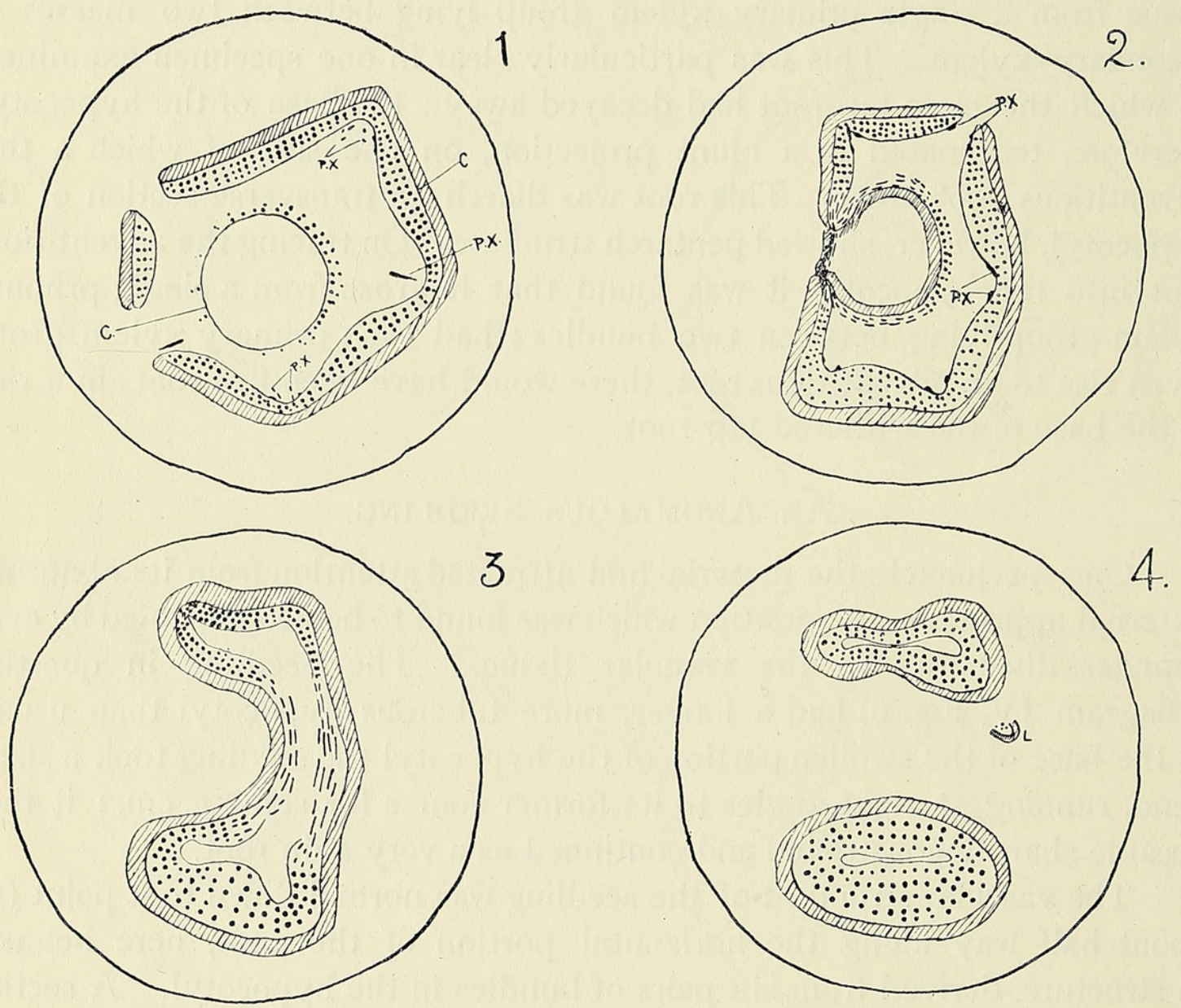

DIAGRAM V.

enclosing a pith and surrounded by phloem (Diagram V, Fig. 3). Lower down in the root, the stele tends to straighten out, and it finally splits in a plane at right angles to its greatest breadth. The two segments immediately close up, each forming a single concentric stele, one of which gives off a small strand (l.) ending blindly in the parenchyma at a lower level (Diagram V, Fig. 4).

Both of the steles now divide in a plane at right angles to the first division, and thus give rise to four steles in the root (Diagram VI, Fig. 5). Of these four steles, one $(k$.) appears to die away at a lower level, while the other three go through a complicated series of changes to form the diarch 
root. All three fuse, giving rise to a triangular mass of xylem and phloem enclosing a pith (Diagram VI, Fig. 6); from each angle of this triangle a branch is sent out laterally (Diagram VI, Fig. 7). The exact fate of these branches was not quite established; it is believed that they simply died out in the parenchyma, although the possibility is not excluded that they went to supply secondary roots. At all events, the remainder of the triangular mass rounds itself off to form a single concentric oblong stele. In the centre of this stele a little diarch xylem plate now appears; it seems to arise

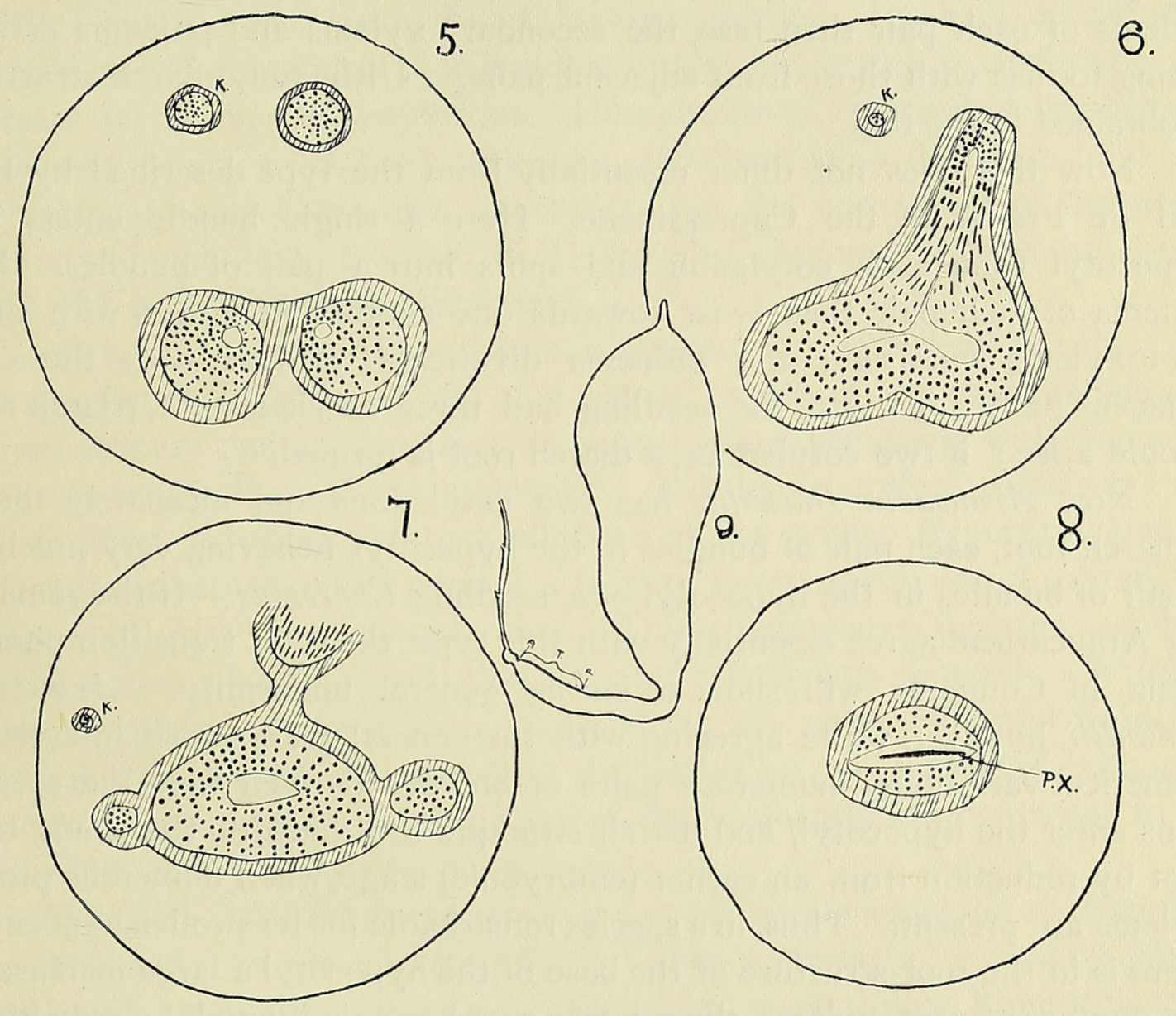

DIAGRAM VI.

by the separation of the protoxylem from the inner surface of the secondary xylem of the stele (Diagram VI, Fig. 8). Throughout the whole of the seedling enormous resin ducts run longitudinally in the cortex, and at the point at which the root becomes diarch frequent anastomoses occur.

\section{CONCLUSTONS.}

The essential points of the above type of seedling structure seem to lie in the variation in the number of cotyledonary bundles entering the hypocotyl, in the number of protoxylem groups in the root, and in the reduction of the structure in the younger portions of the latter. 
As mentioned above, it was not possible, as a general rule, to trace the relationship of the cotyledonary bundles to those appearing in the hypocotyl. This was probably due to the large amount of secondary thickening in all the specimens; had younger seedlings been available there is no doubt that the connexion, of which there were strong indications in two specimens (Diagram III), would have been substantiated. It will be remembered that in these two seedlings each pair of bundles in the hypocotyl was traced back, in the one case to a pair of bundles in the cotyledonary tube, in the other to a single arc-shaped strand which divided. The protoxylems of each pair then fuse, the secondary xylems and phloems divaricating to fuse with those from adjacent pairs. Ultimately diarch structure is obtained in the root.

Now this does not differ essentially from the type described by Hill and de Fraine in the Cupressineae. Here a single bundle enters the hypocotyl from each cotyledon and splits into a pair of bundles. The xylems of each pair then twist towards one another and fuse, with their protoxylems external; the phloems divaricate to fuse with those of adjacent pairs. Thus, if the seedling had three cotyledons, a triarch root should arise ; if two cotyledons, a diarch root is formed.

Now Araucaria Bidwillii has two cotyledons and ultimately forms a diarch root, each pair of bundles in the hypocotyl behaving very much as a pair of bundles in the hypocotyl of a seedling Cupressus. If the remaining Araucarieae agree essentially with this type, then the transition phenomena in Coniferae will show a strong general uniformity. Avaucaria Bidwillii, however, while agreeing with the general plan, shows interesting numerical variations-numerous pairs of bundles derived from the cotyledons enter the hypocotyl, and diarch structure is attained in the young taproot by reduction from an earlier (embryonic) stage, when numerous protoxylems are present. Thus, in a species remarkable for its swollen hypocotyl, there is in the root-structure at the base of the hypocotyl a large increase in the number of protoxylems, the primary root becoming diarch by reduction.

This at once suggests a comparison on anatomical grounds with the seedling of Eranthis hyemalis. In this plant there is a tetrarch structure in the tuberous hypocotyl at the base of the cotyledonary tube, this structure becoming reduced to diarch as the hypocotyl merges into the main root. As is well known, this tetrarch structure has been compared with that occurring in Anemarrhena, and it has been made the basis of wide phylogenetic speculation. It was, however, early suggested (Tansley, 5) that, since diarch structure prevailed almost exclusively in the hypocotyl of nontuberous species of Ranunculaceae, the increase in number of xylem groups in the tuberous Evanthis should probably be correlated with the increased need for vascular tissue in such a structure rather than be regarded as an ancestral trait. 
In Araucaria Bidrwillii the same variation in internal structure is associated with a similar abnormality in the external morphology. In other words, numerous protoxylem groups prevail at the base of a tuberous hypocotyl. Moreover, the number of these groups shows considerable variability, seedlings with heptarch, hexarch, or pentarch structure being equally common. It was not possible to trace any relationship between the degree of tuberosity of the hypocotyl and the variation in the number of protoxylem groups in the root structure at its base, although this variability may be looked upon as evidence that the structure at this point is the result of the operation of biologic factors. In the Cupressineae an increase in the number of bundles in the hypocotyl is caused by an increase in number of cotyledons. Here, however, certain bundles behave as though coming from half-cotyledons, and there is no deviation from the normal character of the root structure. But the occurrence of heptarch, hexarch, or pentarch structure in A. Bidzillii obviously cannot be correlated with any splitting of cotyledons.

Some seedlings, in which the main tap-root was rather shorter than the average for the specimens, did not attain to diarch structure, remaining triarch, or even pentarch in the case of specimens beginning with heptarch structure at the base of the hypocotyl. It takes, therefore, some time for the seedling to obliterate the influence of its swollen hypocotyl and to reduce its structure to the normal. In very young seedlings, of course, the root would show no such reduction. This circumstance perhaps accounts for the statement by Borzi ( 1 ) that the root was always pentarch. Another tuberous species, $A$. imbricata, shows, as far as can be gathered from the existing description, an essential similarity to $A$. Bidwillii, although numerous protoxylems in the base of the hypocotyl do not seem to be so distinct as in the latter species.

Thus the relationship between the seedling structure of $A$. Bidwillii and the usual type shown by seedling Conifers seems to be exactly paralleled by that subsisting between Eranthis and the remaining Ranunculaceae. It is difficult to avoid the conclusion that the similar peculiarity in habit is directly connected with the corresponding abnormalities in structure. While in any one natural group of plants the transition phenomena may show a unity in the general method, yet the actual number of separate xylem groups in the root seems to depend upon the particular character of the individual. Any variation from the normal number of protoxylem groups in an aberrant species seems not likely to be of serious taxonomic value, but is more probably to be correlated with the habit of the seedling. The study of seedling anatomy from a biological standpoint probably offers a more fruitful subject for investigation than is likely to be afforded by the attempts made to found far-reaching conclusions upon the vagaries of seedling structure. 


\section{Shaw.-The Seedling Structure of Araucaria Bidwillii.}

There yet remains to be considered the seedling which showed the anomalous structure. Two points stand out clearly in this-the occurrence of inverted vascular tissue, and the production of several steles. In another group of plants, the Cycads, Worsdell (6) considers that the presence of inverted vascular bundles is evidence of the derivation of these plants from polystelic ancestors, the inverted vascular bundles in modern Cycads being interpreted as the remnant of the interior portion of a formerly concentric stele whose peripheral segment forms part of the normal vascular ring. It is interesting to note that the polystelic stage in Araucaria Bidwillii is derived from a stage with inverted vascular tissue, this inverted vascular tissue forming the segment of each stele lying nearest the centre of the root. Thus the inverted vascular tissue gives rise to that part of each stele which it should do if Worsdell's theory of the Medullosean origin of Cycads is correct.

The value to be attached to this abnormal anatomy depends upon the value which we attach to seedling anatomy as a phylogenetic criterion, and not less on the still wider consideration as to the phylogenetic value of teratological phenomena in general.

As a rule it has been shown that deviations from the normal number of protoxylems and of cotyledonary bundles should not be made the basis of phylogenetic speculation; they are probably correlated with other, and more local, factors in the development of the seedling. The question remains how far the habit of the seedling can influence the development of its vascular tissue ; that variable conditions can under normal circumstances influence the amount produced seems clear, but whether the more striking abnormalities in structure are due to the same cause is doubtful.

Worsdell postulates that of all the regions in a plant likely to show ancestral traits the cotyledonary or first node is one of the most favourable. He cites the case of Encephalartos Barteri, which showed three steles in the hypocotyl, a structure which he considers as recalling Medullosean ancestry. Are we to attach the same meaning to the polystely of Arancaria Bidruillii? The part played by the inverted vascular tissue in the formation of the stele certainly favours this view. On the other hand, is there any external feature in the seedling which distinguishes it from the normal type and would point to its having grown under different conditions? A reference to Diagram VI, Fig. 9, shows at once the peculiarity of the specimen which has already been described (p. 327). The polystelic zone $(t$.) occurs in the upper part of the root, which is here horizontal, the base of the hypocotyl having been sharply bent, and immediately precedes a sharp constriction beyond which the root is much thinner and of the normal diarch type. Whether this constriction necessitates diarch structure in the subsequent and thinner part of the root, and therefore the rapid production of this from a closely adjoining part with hexarch structure leads to the 
complicated series of fusions and divisions described, is a matter on which it is hardly safe to express an opinion. The fact that several of the independent strands seem to end blindly in the parenchyma suggests that there are some definite factors which operate in the rapid reduction in amount of the vascular tissue before it reaches the constricted zone. In fact the phenomenon is perhaps to be attributed to the indirect effect of an injury, or to the action of some unfavourable conditions under which the seedling grew.

\section{SUMMARY.}

(I) The transitior phenomena in Araucaria Bidwillii follow in broad outline the general method already described for other Gymnosperms.

(2) The number of bundles entering the hypocotyl from the cotyledons is very numerous and variable.

(3) The number of protoxylem groups in the root structure at the base of the hypocotyl is also numerous and variable.

(4) There is a reduction in the number of protoxylem groups in the younger parts of the root, diarch structure being finally attained.

(5) The differences between the normal type of transition in Gymnosperms and that in Araucaria Bidwillii are probably due to the tuberous nature of the latter, and are to be compared with those between the normal type of transition in Ranunculaceae and that in Evanthis.

(6) A single specimen with abnormal external features showed aberrant internal anatomy producing numerous steles in the root.

In conclusion, I desire to express my thanks to Professor Farmer, F.R.S., for his constant help and valuable advice throughout the progress of the research.

Royal College of Science.

February, I909.

\section{BIBLIOGRAPHY.}

1. BorzI, A. : Biologia della germinazione dell' Araucaria Bidwillii. Bot. Jahrb., ii, 1905 , p. 273 .

2. Hill, T. G., and de Fraine, E.: On the Seedling Structure of Gymnosperms. Annals of Botany, vol. xxii, 1908.

3. SARGANT, E. : Theory of the origin of Monocotyledons, founded on the structure of their Seedlings. Annals of Botany, vol. xvii, I903.

4. Seward, A. C., and Ford, S. : The Araucarieae, Recent and Extinct. Phil. Trans. Roy. Soc., London, vol. cxcviii, ser. B, I 906.

5. Tansley, A. G. : Reduction in Descent. New Phytologist, vol, i, I902.

6. Worsdeli, W. C. : Structure and origin of Cycadaceae. Annals of Botany, vol. xx, I go6. 
334 Shaw. - The Seedling Structure of Avaucaria Bidwillii.

\section{EXPLANATION OF FIGURES IN PLATE XXI.}

Illustrating Mr. F. J. F. Shaw's paper on the Seedling Structure of Araucaria Bidwillii.

Abbreviations used: $c$. cotyledonary tube; $p l$. plumule; $p . x$. fused primary xylems; $p . x^{\prime}$. primary xylems of bundles ; $x$. secondary xylem; $h$. phloem.

Fig. I. Seedling.

Fig. 2. Bundle in the hypocotyl showing separate primary xylem. $\times 100$.

Fig. 3. Fusion of primary xylems of a pair of bundles in the hypocotyl. $\times 100$.

Fig. 4. Fusion of two protoxylem groups in the root. $\times 100$. 
Annals of Botany

Vol.XXIII,PZ.XXI.
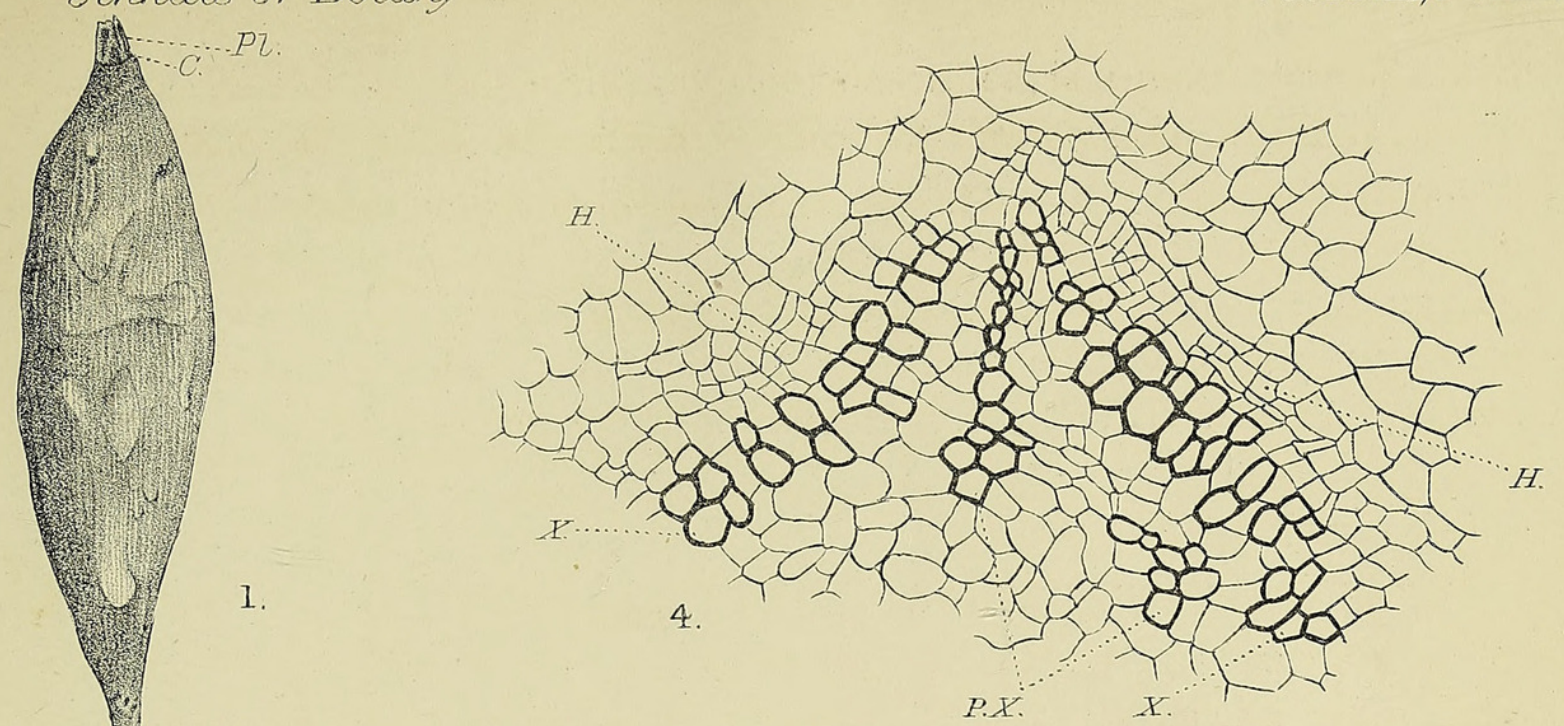

1

सेत्रित

- 1 intal sit
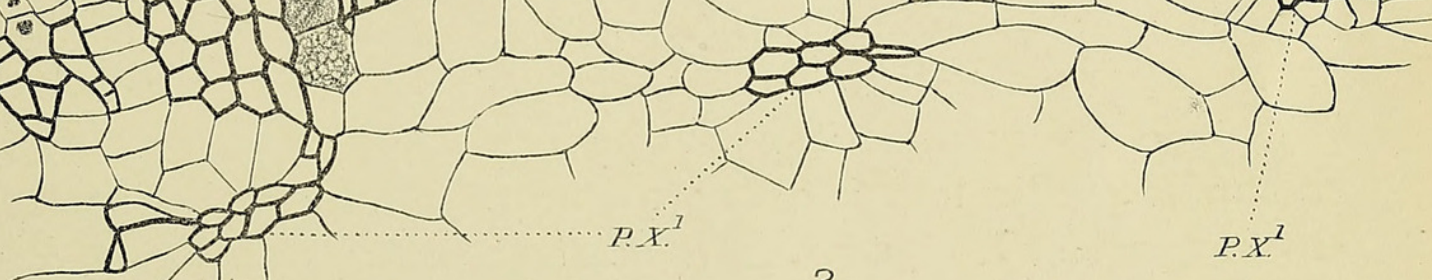

2

,

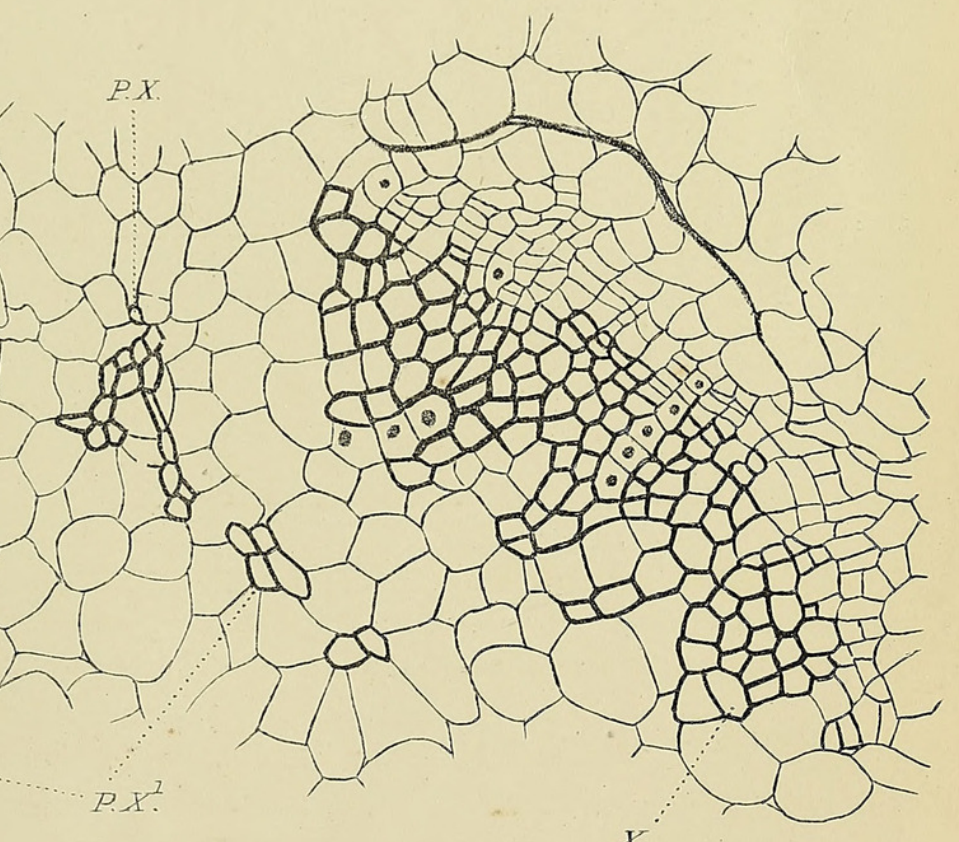




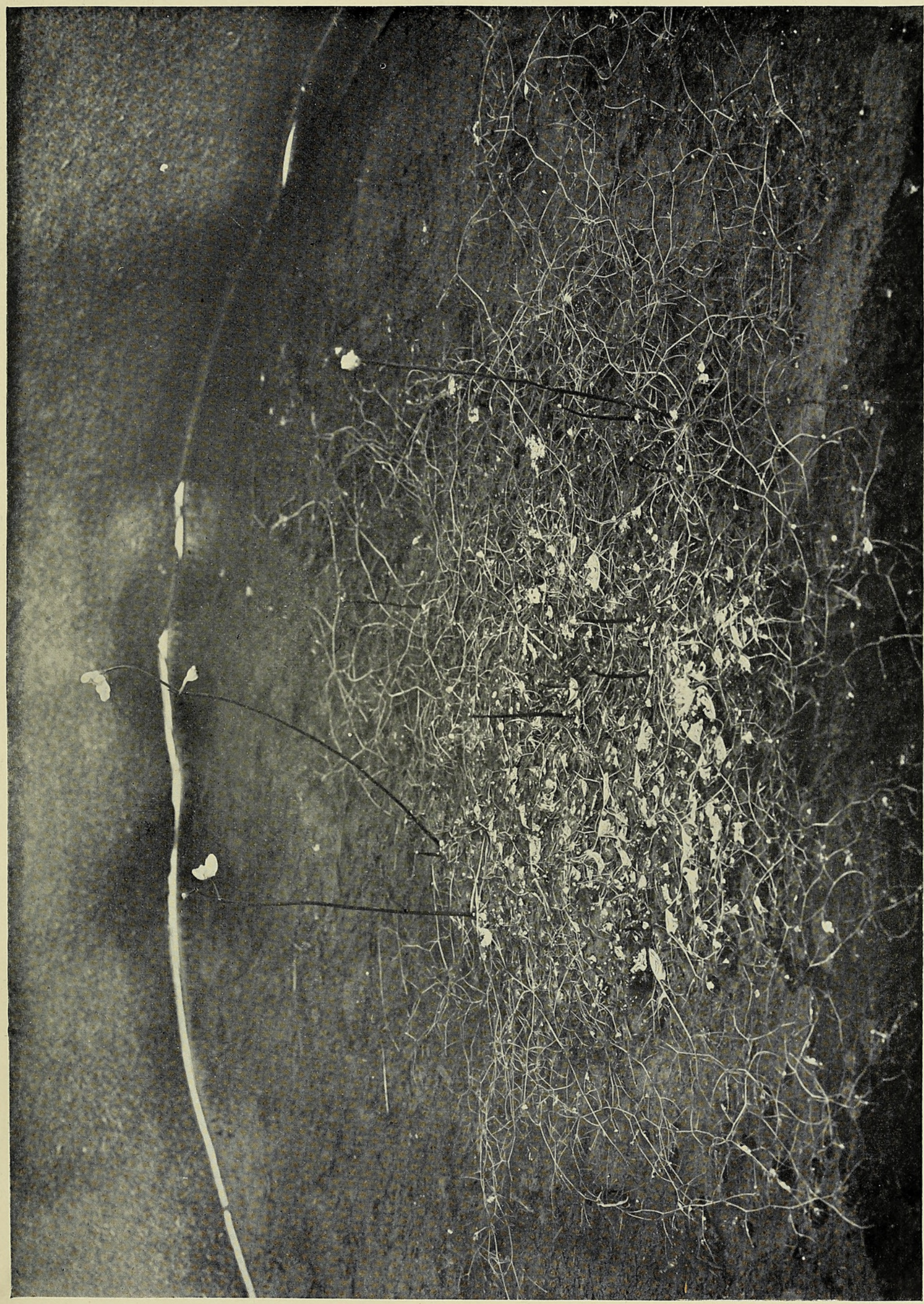

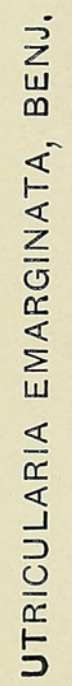




\section{$2 \mathrm{BHL}$ Biodiversity Heritage Library}

Shaw, F. J. F. 1909. "The seedling structure of Araucaria bidwillii." Annals of botany 23, 321-334. https://doi.org/10.1093/oxfordjournals.aob.a089216.

View This Item Online: https://www.biodiversitylibrary.org/item/236540

DOI: https://doi.org/10.1093/oxfordjournals.aob.a089216

Permalink: https://www.biodiversitylibrary.org/partpdf/318952

\section{Holding Institution}

Smithsonian Libraries

\section{Sponsored by}

Biodiversity Heritage Library

\section{Copyright \& Reuse}

Copyright Status: Not in copyright. The BHL knows of no copyright restrictions on this item.

This document was created from content at the Biodiversity Heritage Library, the world's largest open access digital library for biodiversity literature and archives. Visit BHL at https://www.biodiversitylibrary.org. 